\title{
The taxonomic diversity of the microbial community of rivers within oilfields in Khanty-Mansi Autonomous Okrug - Ugra
}

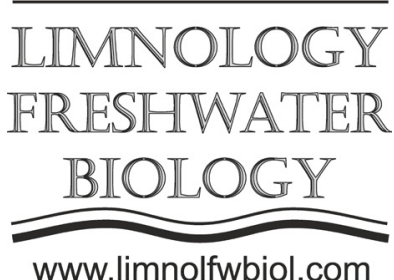

\author{
Arslanova M.M.*, Shornikova E.A. \\ Surgut State University, Lenina av., 1, Surgut, 628400, Russia
}

\begin{abstract}
The analysis of the taxonomic diversity of bacterial and mycelial communities in the rivers located within oilfields in Khanty-Mansi autonomous okrug-Ugra is carried out. 16 bacterial cultures and 4 cultures of mycelial microflora were identified among isolated microorganisms. The qualitative composition of the microbiota of the rivers depends on the location of the river, the anthropogenic load intensity, the hydrological season, which is explained by surface runoffs from the catchment area, as well as the beginning of navigation period.
\end{abstract}

Keywords: microbial community, bacterial microflora, mycelial microflora, taxonomic composition, diversity, oilfields

\section{Introduction}

One of the ways to optimize the system of ecological monitoring of rivers (especially anthropogenic disturbed ones) is to study the quantitative and qualitative structure of microbial communities, since they, on the one hand, play an important role in the processes of destruction and transformation of organic substances (Muchkina et al., 2003), thereby directly participating in the formation of the chemical composition of water; on the other hand, they determine the degree of suitability of water for human use (Savichev et al., 2002).

Natural fluctuations in river microbiocenoses occur continuously; however, anthropogenic activity leads to a change in the composition and structure of microbial communities. Thus, the aim of this work was to characterize the taxonomic diversity of the identified microorganisms isolated from the river water samples.

\section{Materials and methods}

The objects of the study were 20 rivers located within the boundaries of the oilfields in Surgutsky (Vynga, Minchimkina and it's right tributary, Bystryi Kulhegan, Kavyk, Tapyaun, Yakyavin, Komarya, Virsiyavin, Pim) and Oktyabrsky regions (Ob, Bolshaya Leushinskaya, Malaya Leushinskaya, Bolshaya Karymkarskaya, Malaya Karymkarskaya, Kurnisoim, Bolshoy Okhtach, Hompa, Malyi Atlym, Ovynegan) of Khanty-Mansi autonomous okrug-Ugra. Surface water sampling was carried out in accordance with the requirements of Federal standard GOST 31861-2012
(2019). Microbiological analysis was carried out by the in-depth method (Monitoring..., 2001) with the appropriate dilution culturing on universal and selective media. The morphology of cells and colonies, motility, the presence of spore formation, physiological and biochemical characteristics, Gram stain, and cultural properties were taken into account in accordance with classical microbiological methods (Vinnikova et al., 2011). Identification was carried out using the manuals (Bergey's manual..., 1984; Bilay, 1988).

\section{Results}

Bacterial and mycelial communities form an important part of the aquatic ecosystem. Undoubtedly, the microorganisms inhabiting waterbodies within the oilfields are in a certain way adapted to existence in such an environment. All known groups of microorganisms are able to live in the water, but bacteria are the most significant component among hydrobionts. It is well known that the cytoplasmic membrane of bacteria has the ability to actively transport nutrients through the cell wall. That's why, bacteria are able to consume a nutrient substrate present in negligible concentrations (about $1-5 \mathrm{mg} / \mathrm{g}$ ).

Among the isolates extracted from water samples 16 bacterial cultures from 11 families were identified according to the taxonomy (Table).

The study of the mycological composition of the water samples demonstrates their small biodiversity, which is probably due to the specific conditions of their location (low temperatures, high insolation, presence of toxic substances). Microscopic fungi from 
Table. Taxonomic position of bacteria isolated from the studied rivers

\begin{tabular}{|c|c|c|c|}
\hline Category & Group & Family & Genus \\
\hline Gram-negative & $\begin{array}{l}\text { Gram-negative, aerobic / microaero- } \\
\text { philic sticks and coccus }\end{array}$ & $\begin{array}{c}\text { Pseudomonadales } \\
\text { Bacteriacea }\end{array}$ & $\begin{array}{c}\text { Azomonas, Alcaligenes, } \\
\text { Methylobacterium, } \\
\text { Pseudomonas } \\
\text { Flavobacterium }\end{array}$ \\
\hline \multirow[t]{5}{*}{ Gram-positive } & Gram-positive coccus & $\begin{array}{l}\text { Deinococcaceae } \\
\text { Peptococcaceae } \\
\text { Planococcaceae } \\
\text { Micrococcaceae }\end{array}$ & $\begin{array}{l}\text { Deinococcus } \\
\text { Sarcina } \\
\text { Planococcus } \\
\text { Micrococcus }\end{array}$ \\
\hline & $\begin{array}{c}\text { Gram-positive sticks and coccus form- } \\
\text { ing endospores } \\
\end{array}$ & Bacillaceae & Bacillus \\
\hline & $\begin{array}{l}\text { Gram-positive non-spore-forming } \\
\text { sticks of irregular shape }\end{array}$ & $\begin{array}{c}\text { Micrococcaceae } \\
\text { Actinomycetaceae } \\
\text { Nocardiaceae }\end{array}$ & $\begin{array}{l}\text { Artrobacter } \\
\text { Actinomyces } \\
\text { Rhodococcus }\end{array}$ \\
\hline & $\begin{array}{l}\text { Aerobic chemolithotrophic bacteria } \\
\text { and related organisms }\end{array}$ & Nitrobacteriaceae & $\begin{array}{c}\text { Nitrobacter } \\
\text { Nitrosomonas } \\
\end{array}$ \\
\hline & Gram-positive anaerobic bacteria & Eubacteriaceae & Acetobacteium \\
\hline
\end{tabular}

the families Moniliaceae (Aspergillus sp., Penicillium sp.), Dematiaceae (Cladosporium sp.) and Mucoraceae (Mucor sp.) were found more frequently.

\section{Conclusions}

As a result of identification of the isolated cultures, it was revealed that bacterial microbiota predominates in the structure of the microbial community. When studying the composition of mycelial microbiota, only mold fungi were isolated (Cladosporium sp., Aspergillus sp., Penicillium sp., Mucor sp.). The structure of the microbial community is mostly determined by the river and the catchment area size, character and intensity of the anthropogenic load, and the hydrological season.

\section{References}

Bilay V.I. 1988. Aspergilly: opredelitel' [Aspergillus: identification guide]. Kiev: Naukova Dumka. (in Russian)
Vinnikova O., Samoilov A., Popova Yu. 2011. Vydeleniye i identifikatsiya bakteriy [Isolation and identification of bacteria]. Kharkov: Kharkov National University. (in Russian) GOST 31861-2012. 2019. General sampling requirements. (in Russian)

Monitoring i metody kontrolya okruzhayushchey sredy [Monitoring and methods of control of the environment]. 2001. In: Afanasyev Yu., Fomin S., Menshikov V. et al. (Eds.). Moscow: Publishing House of MNEPU. (in Russian)

Muchkina E., Trusova M., Gladyshev M. et al. 2003. Bacterioplankton of a suburban recreational pond and its relationship with hydrobiological, hydrochemical and sanitary-epidemiological indicators. Sibirskiy Ekologicheskiy Zhurnal [Siberian Journal of Ecology] 10: 257-266. (in Russian)

Bergey's manual of systematic bacteriology. 1984. Baltimore: Williams and Wilkins.

Savichev O., Nalivaiko N., Trifonova N. 2002. Microbiological composition of river waters in the basin of the Upper and Middle Ob'. Sibirskiy Ekologicheskiy Zhurnal [Siberian Journal of Ecology] 9: 173-180. (in Russian) 